Archives de sciences sociales des religions

135 | juillet - septembre 2006

Réveils du soufisme en Afrique et en Asie

\title{
On snacks and saints: when discourses of rationality and order enter the Egyptian mawlid
}

Samuli Schielke

\section{(2) OpenEdition}

1 Journals

\section{Electronic version}

URL: http://journals.openedition.org/assr/3765

DOI: $10.4000 /$ assr.3765

ISSN: $1777-5825$

Publisher

Éditions de l'EHESS

\section{Printed version}

Date of publication: 1 September 2006

Number of pages: 117-140

ISBN: 2-7132-2093-9

ISSN: 0335-5985

\section{Electronic reference}

Samuli Schielke, "On snacks and saints: when discourses of rationality and order enter the Egyptian mawlid ", Archives de sciences sociales des religions [Online], 135 | juillet - septembre 2006, Online since 16 October 2009, connection on 19 April 2019. URL : http://journals.openedition.org/assr/3765 ; DOI : 10.4000/assr.3765 


\section{Samuli Schielke}

\section{On snacks and saints: when discourses of rationality and order enter the Egyptian mawlid ${ }^{1}$}

Mawlid festivals, which are celebrated annually at the shrines of saints, ${ }^{2}$ are probably the most colourful and most controversial element of Sûfî practice in contemporary Egypt. These festivities are typically characterized by a special festive atmosphere where devotion and entertainment come together in an overwhelming spectacle of crowds, lights, music, pilgrims, Sûfî $d h i k r$, trade and amusements. ${ }^{3}$ Although the number of visitors at mawlids has been declining since the mid1990s, they still attract up to hundreds of thousands of visitors and represent an extraordinary moment of public mobilization.

Mawlids have a close bond to specific locations and a specific arrangement of space. A mawlid is a celebration of the shrine, and a celebration around the shrine. All of these shrines have their share in a grand sacred history - both physical and imagined - of holy women and men ${ }^{4}$ and of sacred places. It is not my intention, however, to analyse this history here. Islamic or pre-Islamic continuities of the sacred spaces are not the focus of my attention here. Instead, this study will focus on some very contemporary discontinuities and ruptures in

1. This article is based on papers presented in a public lecture at the Netherlands-Flemish Institute in Cairo on 23 January 2003, and in the workshop "Modern adaptations of Sûfîbased popular Islam: concepts, practices and movements in a translocal perspective" at the Centre for Modern Oriental Studies, Berlin on 4 April 2003. An earlier version was published in Georg StaUth, ed., On Archaeology of Sainthood and Local Spirituality in Islam. Past and Present Crossroads of Events and Ideas (Yearbook of the Sociology of Islam, vol. 5), Bielefeld, Transcript Verlag, 2004, p. 173-194.

2. In Egypt, Muslim saints (awliyâ') are usually Suffî shaykhs and/or descendants of the Prophet. Hoffmann, 1995, p. 89ff. The term mawlid (colloquial mûlid, pl. mawâlid) derives from the Prophet's birthday (mawlid al-nabî). Elsewhere in the Muslim world similar festivals have different names, for example mawsim in Morocco, urs in the Indian sub-continent, hauli in East Africa and khawl in Indonesia. (Cf. "Ziyâra" in Encyclopaedia of Islam). A rich tradition of Christian saints, monasteries and mawlids also exists in Egypt (FrANKFURTER, 1998; MeInARDus, 2002), however as the Christian tradition has not been subject to controversies and reforms to the same extent as the Muslim tradition has, I have not included Christian mawlids in this study. 1990.

3. For descriptive studies on mawlids, see MCPherson, 1941, Mustafa, 1981 and Biegman,

4. Cf. SHa'RÂNî, 1997. 
the festive practices at sacred Islamic locations around Egypt. Through the analysis of present-day mawlids I intend to shed light on the contemporary tensions that exist between different understandings of sanctity, festivity, and the respective arrangement of space and time.

\section{Critics of mawlids}

Ever since they exist, ${ }^{5}$ mawlids have been subjected to criticism. ${ }^{6}$ This criticism, part of a tradition of ritual reform as represented by Ibn Taymiyya and Ibn 'Abd al-Wahhab, was based on the claim that mawlids are a bid'a, an illegitimate innovation in Islamic ritual. ${ }^{7}$ Although historically mawlids are an innovation in Islam, it is worth noting that this critical tradition remained largely marginal for a long time, and in an intellectual and religious atmosphere favourable for Sufism, mawlids were seen to be a bid'a hasana, a praiseworthy innovation. ${ }^{8}$ This old and still ongoing debate about bid' $a$ calls into our attention how much the religious assessment of a practice depends upon social and ideological factors external to the religious scripture. What in Muslim scholarly tradition makes a practice an illegitimate bid'a, is not just that it is not sanctioned by the Qur'ân and the Sunna, but that it is seen to compromise the purity of sacred practices, the validity of the canonic texts and rituals, or the identity of Islam against other religions. ${ }^{9}$ Hence, what counts as forbidden bid $a$ is always related to historical and ideological circumstances. These circumstances changed in the late $19^{\text {th }}$ and early $20^{\text {th }}$ centuries when the critical tradition underwent a qualitative change as part of the modernizing and nationalist discourses. For many of the modernizing elites and the Islamic reform movements, mawlids became a symbol of the dark backwardness and ignorance which, in their view, held back the development of Egyptian society. The critical discourse shifted from individual moral and salvation to the civilizational and moral quality of the nation. In this discourse - which today represents one of the common grounds of modernism and Islamic reform in Egypt - mawlids appear as an expression of ignorance and backwardness,

5. The origin of mawlids is subject to controversy. It is often assumed that mawlids represent a pre-Islamic continuity of Pharaonic traditions (McPHERSON, 1941; STAUTH, 2001), but this possible continuity is highly speculative and lacks evidence from historical data (MAYEURJAOUEN, 1995, p. 71). Another current theory is that mawlids were introduced by the Fatimid rulers of Egypt between the $10^{\text {th }}$ and $12^{\text {th }}$ century and represent a continuation of Fatimid Shiite practice (MusTAFA, 1981, p. 80-84). However, the mawlids of the Fatimid court were essentially public celebrations of the ruling elite rather than popular festivals. Mawlids as we know them today - popular pilgrimages to a saints' shrine, combining religious and profane festivities are only documented from the $14^{\text {th }}$ and $15^{\text {th }}$ centuries on (DE JonG, "Mawlid", Encyclopaedia of Islam, Shoshan 1993, p. 17).
6. Shoshan, 1993, p. 17ff.; Kaptein, 1993.
7. Fierro, 1992, p. 204.
8. WINTER, 1982, p. 179-184.
9. Fierro, 1992, p. 214. 
an illegitimate innovation in Islam, a shameful remainder of primitive rituals, the very opposite of religion and rationality. ${ }^{10}$

Closer examination reveals, however, that there is actually little inherently un-Islamic or anti-modern about celebrating a saint. Salafi discourses do judge the veneration of saints to be a form of shirk, arguing that the belief in the intercession (tawassul) and blessing (baraka) of the wali is opposed to the absolute power of God. However, although the actual practice of saint veneration is highly contested, only the most radical Wahhabi critics actually dare to question the very basics of sainthood. ${ }^{11}$ After all, the special status of saints or "friends of God" (awliyâa' Allâh) is explicitly mentioned in the Qur'ân (10:62), and the major saints of Egypt enjoy a high level of public recognition. What really makes a mawlid appear irrational and un-Islamic in the view of so many modernists and Salafi reformists, is primarily its specific festive and ecstatic character. In the following I will argue that mawlids are primarily a problem for the specific interpretations of order and rationality, religiosity and sanctity that predominate in the official public sphere of contemporary Egypt; and that this is also the starting point of all attempts to reform mawlids.

\section{Festive time and space}

When the participants of a mawlid are asked what the festivity is about, the answers they provide vary significantly: some refer to the pilgrimage to the shrine, the love of abl al-bayt and the saint's baraka, while others speak of the congregation of friends and brethren, the $d h i k r$ sessions, the meditation and recitation. Others simply find the mawlid great fun, with crowds, lights, music, and the colourful fascinating world of inexpensive popular amusements. The festivities also provide a livelihood for a large number of people.

In most cases the different motives for celebrating a mawlid are not clearly distinguished. The search for blessing and spiritual experience goes hand in hand with the fascination of the festive atmosphere. Like no other occasion in Egypt, a mawlid is an ambivalent mixture of religious and profane elements. Much of the religiosity expressed in a traditional mawlid is emotional and ecstatic and expressed in conjunction with music and dancing and a strong belief in miracles.

Unlike many other festive occasions in Egypt, a mawlid is a carnivalesque utopian festival, during which many of the boundaries and norms of ordinary life are temporarily suspended. I refer here to Mikhail Bakhtine's understanding of the carnival as a symbolic, temporary suspension of the "normal" order of

10. 'Umar, 1902, p. 255ff.; 'Abd al-Latif, 1999; Johansen, 1996, p. 134ff., 161ff.; SCHIELKe, 2003.

11. Interview with activists of the Wahhabi group Ansâr al-Sunna al-Muhammadiyya in Cairo, 15 December 2002. 
things. According to Bakhtine, carnival time is not merely a "safety-valve" that helps people to endure the hardship of daily life, carnival is also a time in its own right, a cheerful, grotesque popular utopia of freedom and equality. It is ambivalent by default; it serves the cohesion of society, but also has a subversive element. ${ }^{12}$

In the narratives of pilgrims and visitors, the mawlid indeed emerges as a utopian moment beyond the boundaries of daily life, a place where all people from all classes of society unite and where the mystic and the thief come together in the realm of the saint - a beautiful congregation with the Sûfî brethren, a moment of freedom far removed from home and daily routines. During the mawlid you can "leave behind your work and family and set for a long, hard journey", "get a breath of fresh air", "see strange, new things" and "forget all your worries and live in the moment." 13

The festive space of the mawlid is characterized by an overwhelming and chaotic appearance. The streets are filled with pilgrims' carpets, merchants' stands, tents of the Sûfî orders, popular amusements and roaming crowds. This is also reflected in colloquial Egyptian idioms in which the term mûlid (colloquial for mawlid) is used to express chaos and confusion. ${ }^{14}$

This festive chaos is not total; it does follow a certain pattern of order, however the order in question is festive and ambivalent in nature. One can best imagine the festive space of the mawlid in the shape of a space consisting of a series of overlapping circles: in the middle of it all stands the shrine of the saint, the focal point and the very reason behind the festivity and a source of holiness and baraka. Around it, the Sûfî festivities take place, a strongly spiritual and ecstatic experience for the participants. But the mosque is also encircled by countless stands of the vendors, and - sometimes mixed with the Suffi celebration, sometimes further out in the margins of the festivities - swing boats, popular singers and all of the other popular amusements that make up the mawlid. Surrounding streets and alleys are filled by a neighbourhood celebration, with families sitting in front of their houses and in cafés. People move continuously between the

12. BaKhtine, 1968 , p. $5 \mathrm{ff}$. One could also analyse this festive time in terms of Victor TURNER's (1974) concepts of liminality and communitas. However, Bakhtin's model has the major advantage that it helps to explain the subversive nature of mawlids, the potential threat they constitute to concepts of order. According to Bakhtin's logic as opposed to Turner's, the festive days and nights of the mawlid are not merely a passing moment of anti-structure about to turn structure again, but a temporary alternative reality that is strongly utopian in character.

13. Descriptions recorded in Tanta and Disuq in October 2002 and provided by the imam of a mosque in Tanta describing his journey to a mawlid in the desert, a young woman who travels every year with her parents and a Suffi group to a mawlid, a young woman from a family of landless farmers running a temporary café in a mawlid and a male teacher and recent university graduate who visited a mawlid with his friends.

14. As for example in the expression "a mawlid without its master (i.e. the saint)" (mûlid wa-sâbbu ghâyib). 
different spots and the huge crowds $(z a h m a)$ are part of the standard imagery of the festivity. This festivity does not have a clear programme, a clear meaning or a clear plan, however it has a clear centre in its festive geography (both physical and imagined): the shrine of the saint which radiates the aura of sacredness over all of the festivity, encompassing everything and everyone. Thus, even the most profane parts of the festivity are neither separate from nor opposed to the sacred centre; on the contrary they become part of the sacred-profane spectacle. ${ }^{15}$

This festive space and atmosphere are highly problematic for the discourses of modernism and Islamic reform: they are fundamentally opposed to their standards of order and serious and rationalistic knowledge. Yet it is not so much the content of dominant values and norms that is relativized in the mawlid, but the boundaries which mark these: not only that between the sacred and profane, but also those between fun and seriousness, male and female, public and private, living and dead, day and night, city and countryside. ${ }^{16}$

The festive order of the mawlid is based on a social order that allows for ambivalence and the temporary reversal of boundaries. In that order, the mawlid is part of the circle of life and plays a legitimate role in both sustaining and criticizing the surrounding ordinary time. As opposed to this, in the modernist discourse of the $19^{\text {th }}$ and $20^{\text {th }}$ centuries, of which the Islamic reform movement is a part, society is seen in a process of cumulative development, rationalization and perfection. In this kind of discourse, boundaries are universal and the festive time and space of the mawlid appear as a form of retrogression. Hence, what appears as an aura of sanctity over a festivity that unites all of human life in the overlapping circles, mawlid becomes, in the modernist world view, a collection of profane, backward and ridiculous practices that taint the purity of the sacred sphere.

This phenomenon is illustrated particularly well by the issue of roasted chickpeas - a cheap tasty snack and a common souvenir purchased at a mawlid. In the mawlid the chickpeas share in the sacred aura of the festival as carriers of baraka, to the degree that in the colloquial idiom chickpeas have come to represent something like an archetypical symbol of mawlids. ${ }^{17}$ In the critical discourse on mawlids, chickpeas become a problem. A religious newspaper ${ }^{18}$ commented disapprovingly on the mawlid of the late TV preacher Muhammad Mutawalli al-Sha'rawi: ${ }^{19}$ "The mawlid of al-Sha'rawî turned into a playground of dervishes, a festival of chickpeas, sweets and children's play." Although in themselves

\footnotetext{
15. MADqeuF, 2001.

16. Madefuf, 2001; Pagès-el-Karoui, 2002.

17. For example, "leaving the mawlid without chickpeas" (tili' mi-l-mûlid bi-lâ hummus), which means "missing an opportunity".

18. 'Aqîdatî, 22 June 1999.

19. For the the person of al-Sha'râwî and his mawlid, cf. ISKANDER, 2000; SCHIELKe, 2001; Chin, Mayeur-JaOUen, 2002.
} 
chickpeas are in no way opposed to Islam, modernity, civilisation or anything such like, their presence in the celebration of the saint can make them appear so. Here, chickpeas - part of the flourishing trade in sweets, snacks, amulets, toys and souvenirs - symbolize the blurring of the boundaries which ought to define the proper place of both snacks and saints.

\section{Reform discourses and practices}

Most of the critics of mawlids in the official public sphere do not demand that the festivities be abolished. After all, there are good reasons for the continued organization of mawlids. They represent a major medium of religious mobilization. For Sûfî orders a mawlid is the occasion on which the members of the order meet, the message of Sûfî religiosity can be propagated and the identity of the order is demonstrated towards both members and outsiders alike. ${ }^{20}$ For the state, mawlids represent an apolitical conservative form of religiosity, which should be encouraged in presenting something opposite to Islamist movements and which also provides a good opportunity for the propagation of the official Azhari interpretation of Islam. ${ }^{21}$ In addition, the markets and amusement areas are often important for the local economy.

In response to the numerous critical views which describe mawlids as an uncivilized and un-Islamic bid'a, attempts to reform mawlids have emerged in the recent years. These attempts originate mainly from two directions: from state institutions, which attempt to reorganize the public space of mawlids to give them a more "correct" and "ordered" appearance, and from reformist Sûfî groups, ${ }^{22}$ which criticize the ambivalent atmosphere and the ecstatic rituals of mawlids and reshape their own festive practices to fulfil the requirements set by reformist discourses and the modern public sphere. ${ }^{23}$

20. GiLSENAN, 1973, p. 61-64.

21. Interview in Cairo 8 July 1999 with shaykh 'Abd al-Mu'izz al-Jazzâr, deputy secretary general of Islamic Research Academy (Majma' al-buhûth al-islâmiyya) of al-Azhar; interview in Kafr al-Shaykh 21 January 2003 with Fu'âd 'Abd al-'Azîz Muhammad, director of the Awqâf administration of the province Kafr al-Shaykh; cf. also LuIZARD, 1991, p. $46 \mathrm{ff}$.

22. LUIZARD, 1991; JOHANSEN, 1996.

23. One must observe, however, that reformist Sûfî groups are not separated from the rest of the Sûfî movement in Egypt. There is a wide-spread Sûfî apologetic discourse which is used by various people from the Sûfî milieu to defend Sûfî doctrines and practices against anti-Sûfî discourses. The basic apologetic strategy is to deny that Sufism has any relation to controversial practices and to construct an ideal model of "true" Sûfî practice. Reformist Sûfî groups remain part of the Sûfî milieu, but they stand out from it through the way they act out this discourse in their ritual practice. This is most commonly the case with groups that try to attract members from the upper and middle classes - where Salafi and modernist anti-Sufism have high currency. These groups most urgently need to adapt to the requirements of the dominant public discourses. Cf. Hoffman, 1995, p. 52; FrishKOPf, 1999, p. 1034-1047; СHin, 2000, p. 141-153; 343-347. 
Although they appear separate at an initial glance, these two reformist trends are, in fact, closely interconnected through the influence exerted by the state on the Sûfî orders and the close relationship between reformist Sûfî groups, the Azhar and the state, ${ }^{24}$ all of whom participate in the same discourse on "true" Sufism and "true" mawlid. In this discourse, which is connected to the more general discourses of authenticity, modernity and civilisation, mawlids are seen as occasions of remembering, learning and charity. Any deviations from these ideals that exist are presented as external influences that have nothing to do with the true Islamic core of the mawlid. Consequently, the aim is to eradicate such deviations in the festivity so as to make the mawlid what it ought to be: an occasion for learning from and practising the pious example of the wali. ${ }^{25}$

Since its emergence in the late $19^{\text {th }}$ century, this discourse has been accompanied by attempts to reform the festivities. Ritual and moral reform have the longest history. The emergence of ritual reform coincides with the growing public (both colonial and local) criticism of ecstatic Sûfî rituals, and was marked with the famous ban in 1881 on the spectacular ritual of dawsa, whereby the shaykh of the Sa'diyya order would ride on a horse over the bodies of his disciples. Since the late $19^{\text {th }}$ century and throughout the $20^{\text {th }}$ century, official Sûfî dignitaries tried and to some extent managed to ban other scandalous rituals such as snakecharming and eating broken glass, and - with less success - the use of musical instruments and the participation of women. ${ }^{26}$

The moral reform of mawlids went hand in hand with the growing concern for public morality in Egypt since the $19^{\text {th }}$ century. One possible starting point of this development could be a decree issued in 1834 prohibiting female dancers - who in those days were an inseparable element of all major festivities - from performing in public places. ${ }^{27}$ However, the decree - which never extended beyond Cairo in the first place - was short-lived, and 100 years later dancing, gambling, alcohol and prostitution were still common and visible at mawlids although the state did attempt to alter the situation by closing down some of the most infamous mawlids. ${ }^{28}$ More far-reaching measures to "clean up" the festivities were introduced in the second half of the $20^{\text {th }}$ century. Since the $1950 \mathrm{~s}$ and 1970s, the sale of alcohol has been banned at most mawlids and, today, it is often impossible to find a single bar at a mawlid. Some cities, most importantly Tanta, even impose general prohibition during the festivity. Female dancers, who could still be seen performing on the streets in the immediate vicinity of the

24. LuizARD, 1991, p. 46f. State control of Sûfî orders and sponsorship of Sûfî reform are not a new phenomenon: they have a history dating back to the late $19^{\text {th }}$ century. Cf. DE JONG, 1978.

25. AbÛ L-'AzA'IM, 1991; Ibrahim, 1996; al-Liwâ' al-islâmî, 1 August 2002.

26. De Jong, 1999, 2000, p. 91ff.; Luizard, 1991, p. 28f.; Gerholm, 1997, p. 140.

27. Wallin, 1864, vol. 2, p. 44; Lane, 1989, p. 566, n. 28.

28. MCPherson, 1941, p. 5-16; 286. 
mosque in the $19^{\text {th }}$ century, have been forced to move to the outermost periphery of the festivity and are banned from performing altogether at the majority of mawlids. ${ }^{29}$ Gambling is still a common sight at most mawlids, however it appears to enjoy only a semi-legal status.

The large-scale reorganization of the festive space and the rituals has reached its peak since the 1990s, the period which I will analyse in the following. What is involved here is a more fundamental reform that goes beyond the elimination of the most immoral and scandalous elements from the festivities. The practices I will analyse in the following section are part of the discourse of "true" and "correct" mawlid and their objective is to change the festive space and time of the celebrations.

\section{The making of a mawlid}

Despite its at times very chaotic appearance, a mawlid is by no means a spontaneous event. Major organizational effort is required to stage these apparently chaotic scenes and this provides a means of changing the form and character of the festivity.

Several local-level state institutions participate in the organization of a large mawlid. The festivity is planned and organized by a board comprising different branches of the administration, typically the province governor's office, the city administration, the security, electricity and health authorities and the Awqâf administration. If the mawlid is held in honour of a Sûfî shaykh, the Sûfî order affiliated to him may also participate in the organization. The state institutions allocate space for different parts of the festivity (Sûfî orders' tents, market stands, amusements, cafés etc.) and are responsible for the planning and maintenance of the public space (buildings, streets, parks etc.) and for security and order during the festivity. ${ }^{30}$

The state provides the physical framework for the festivity, but - with exception of official celebrations organized by the Awqâf administration and the Organisation for Cultural Centres (hay'at qusûr al-thaqâfa) - it does not produce the content of the festivity. Most of the actual celebrations are organized on a decentralized basis within the framework provided by the state. The more profane elements of the festivity - cafés, restaurants, amusements, small trade etc. - are commercial and run by countless private entrepreneurs, while most of the religious celebrations are organised by Sûfî orders and Sûfî-minded individuals.

29. VAN NieUWKerk, 1995, p. 65.

30. PAGĖs-EL-Karou, 2002; interview with shaykh Muhammad Hammâd, shaykh of the mosque of Sayyid al-Badawî, on 28 June 1999 in Tanta; interview with Sa'îd Mar'î, secretary general of Qena governorate, on 15 January 2003 in Qena. 
The basic physical unit of Sûfî celebrations at a mawlid is khidma, the services offered to Sûfî brethren and visitors. It is the place where pilgrims sleep during the festival, where free food is offered to the people and where Sûfî gatherings - which traditionally consist mainly of collective $d h i k r$ - take place at night. The concrete form of a khidma can range from a simple carpet on the pavement with a gas-cooker and a teapot to a lavish tent with bright coloured lights where food is served to thousands and where famous munshids perform at night. Each khidma is independently organized by a Sûfî group, as is the form and programme of the gatherings. ${ }^{31}$

Hence, two main channels exist where the discourse of reform can take shape in practice: the involvement of the state in the organization of the festivities, which allows for the manipulation of the festive space, and the Sûfî hadras which provide reformist groups with the best opportunity to practice their version of what mawlid is about.

\section{Reorganizing the public space}

\section{Tanta: sharpening the boundaries}

Over the past ten years, the sites of almost all major mawlids in Cairo have been substantially reconstructed by public authorities. Similar projects have also been carried out in major pilgrimage sites in the provinces, notably in Tanta, Disuq and Qena.

In the Nile Delta city of Tanta, the mawlid of al-Sayyid Ahmad al-Badawî, ${ }^{32}$ Egypt's largest and most famous mawlid, has a long history of government presence. ${ }^{33}$ Due to its tremendous size, ${ }^{34}$ this festivity stretches over several kilometres of festive grounds. The mawlid traditionally has three main spaces: the surroundings of the mosque in the centre of the city, a fair ground behind the railway line, and behind that, the fields of Sigar where most of the tents of the Sûfî orders and pilgrims are located. ${ }^{35}$

31. Cf. Снін, 2000, p. 270-275.

32. QADi, 2001; MaYeur-JaOuen, 1994.

33. Wallin, 1864, p. 123; 135; 143; Martinovich, 1912; Pagés-el-Karoui, 2002. I am indebted to thanks to Philipp Reichmuth for translating Martinovich's article from Russian.

34. The mawlid is estimated to have two million visitors. (Interview with Shaykh Muhammad Hammâd, shaykh of the mosque of Sayyid al-Badawî, on 28 June 1999 in Tanta.) However, as such estimates tend to be vastly exaggerated in Egypt, and there is no reliable way of providing an objective count of the number of visitors, this estimate is little more than a wild guess.

35. This has been the case since the 1940s at least (Interview with Shaykh 'Abd al-'Azîz Faysal, a regular visitor to the mawlid since that time, on 16 October 2002 in Tanta), but this basic arrangement of the festive grounds has been roughly the same much longer (WALLIN, 1864, vol. 2, p. 39-44; MARTINOVICH, 1912). 
State involvement in the festivity has not affected the basic layout of this festival, however it has continuously tended to draw the lines between the different spaces more rigidly so that vendors' stands and entertainment areas are only allowed in specified locations. Most recently, in the 1990s, part of the square in front of the mosque, which used to host a market and a bus station, was surrounded by a fence to turn it into a sanctuary (haram). ${ }^{36}$ During the mawlid, the area inside the fence is covered by pilgrims' carpets and temporary cafés. The large tents of the police, health service, fire brigade and some Sûfî orders stand just outside the fence.

\section{Disuq: creating a representative space}

The reforms of the public space in Tanta have largely followed the preexisting layout of the mawlid. However they have resulted in a far more rigid differentiation between the divisions within the festival. State involvement in some other mawlids clearly opposes the pre-existing festival order. This is the case in the nearby city of Disuq, home to the mawlid of Sîdî Ibrâhîm al-Disûqî. ${ }^{37}$ In the mid-1990s, the mosque square was expanded to give the mosque that houses the shrine a more prestigious environment and to create more space for the mawlid. Since then, the spacious new square hosted the main part of the mawlid. The tents of the Sûfî orders stood in front of the mosque and the rest of the square was filled with trading stands and pilgrims' carpets. The amusements were located in a nearby street. In 2002, however, by order of the province governor 'Ali 'Abd al-Shakûr, ${ }^{38}$ it was forbidden to put up any stands or tents at all in the square during the mawlid (which lasted one week). As a result, the square was only sparsely crowded during the festival, and the celebrations moved to the crowded side streets. The emptiness of the central square was further underlined by an unusually heavy security presence.

Most participants were disappointed about the shape of the festivity. Vendors, Sûfîs and the city's inhabitants all expressed discontent about this new order, complaining that this year the mawlid was "weak", "all government" and "spoiled". The local authorities, however, considered it a great success in making the festivity more ordered, beautiful, representable and religious. ${ }^{39}$

36. Interview with regular Sûfî visitors to the mawlid on 15 October 2002 in Tanta.

37. Ja'fari, 2001; Hallenberg, 1997.

38. In a bizarre twist of fate, the governor died of heart attack on 5 November 2002 (al-Wafd 6 November 2002) only five days after the mawlid, which many Sûfîs immediately interpreted as a divine punishment for his restrictive measures during the mawlid.

39. Interview with Fu'âd 'Abd al-'Azîz Muhammad, director of Awqâf administration in the province Kafr al-Shaykh, on 21 January 2003 in Kafr al-Shaykh city. 


\section{Qena: modernizing the city, relocating the festivity}

This new order that was imposed in Disuq aimed to create an empty ordered and, most of all, representable space in the centre of the mawlid, however it did not attempt any far-reaching relocation or redefinition of the festivity as has been the case in the Upper Egyptian city of Qena, home to the mawlid of Sîdî 'Abd al-Rahîm al-Qinâwî. ${ }^{40}$ This mawlid had traditionally taken place in the immediate vicinity of the mosque, in the large open square in front of the mosque and in the graveyard behind it. Sûfî khidmas, trade and amusements used to spread over the area, often standing side by side. All this changed when the city of Qena experienced a large-scale development campaign after the new governor, State Security General 'Âdil Labîb assumed office in late 1999. ${ }^{41}$

One part of the campaign involved the improvement of the pilgrimage site and the reorganization of the annual mawlid. The mosque in which the shrine is located was renovated and extended. ${ }^{42}$ The open square in front of the mosque, where vendors' stands and large khidmas were previously located, was completely surrounded by a fence and became accessible only from two gates facing the main street, not from side streets or from the graveyard behind the mosque. Unlike in Tanta and Disuq where the squares are open for the public to picnic on and wander about, in Qena most of the square was turned into a park that is completely closed to the public.

During the mawlid, no tents or stands were allowed inside the passage marked by iron fences (one to separate it from the streets, the other to separate it from the park). On the final night of the festival, at maghrib prayer, the entire area of the mosque was closed to the public because the governor and the shaykh al-Azhar were arriving for the official celebration.

As a result of these measures, the physical shape of the mawlid changed significantly. Not only were khidmas and a considerable number of the trade stands forced to wander to the side streets, the graveyard, which had hosted much of the mawlid in the past, was largely cut off from the festive grounds. Furthermore, the amusements were given a new location in the nearby stadium, approximately half a kilometre away from the mosque and the Sûfî tents. The entire festive space was fragmented by numerous fences and gates.

The secretary-general of Qena province ${ }^{43}$ argued in an interview, that these measures had turned the mosque and the mawlid of Sîdî 'Abd al-Rahîm into a beautiful modern Islamic pilgrimage site, a representable and clean place "for people to perform ziyâra and to listen to religious hymns and lectures and

40. AL-HAJJAJî, 1996.

41. Al-Ahrâm, 1 November 1999; 29 August 2002.

42. In many other pilgrimage centres, the renovation of the mosque went hand in hand with a higher degree of gender segregation; however this was not the case in Qena.

43. Sa'î̀ Marî̂, Qena 15 January 2003. 
the biography of Sîdî "Abd al-Rahîm”, completely isolated from any kind of "transgressing activities" (a'mâl mukhilla), such as amusements, gambling, trade, and eating and sleeping in the open.

All these attempts at reorganization result from a specific understanding of the festive order which opposes the traditional model of overlapping circles. The state authorities tend to organize the mawlid increasingly on the basis of a model of separate spheres. In Tanta, this is done by sharpening the boundaries of the existing spatial arrangement, in Disuq through the creation of an empty representative space in the centre that is separate from the popular festivity in the side streets, and in Qena through the radical relocation of the festivity, which was conceived as part of the modernization of the entire city.

In each case, the mawlid space has been restructured in accordance with a functionally differentiated system of order. In this new order, the sacred and the profane, the official and the popular celebrations are separated. Everything (i.e. everything that the planners consider important) has its place. The state symbolically takes possession of the centre of the mawlid by creating an empty, representative space. In the words of the responsible officials and religious dignitaries, this space is "beautiful" and "ordered" (munazzam). Nizâm, meaning order, discipline and organization, is, perhaps, the most common word that is used in the context of the reorganization of mawlids. ${ }^{44}$

This new spatial order of the mosque and the surrounding area looks prestigious and is suitable for official ceremonies. However, it is rather dysfunctional in the context of a mawlid as it fragments the open space required for the large crowds that attend the festivities. The contingent and ambivalent space of a mawlid is turned into a prestigious, well-ordered space in a modern city inhabited by well-disciplined citizens as apparently conceived by planners of such projects. ${ }^{45}$

This emphasis on discipline and order is also expressed in the increased emphasis on religious preaching and propaganda and the large official celebrations (consisting of speeches by religious and political dignitaries and some recitation of the Qur'ân and religious poetry) which are held in the immediate vicinity of the mosque. It is further reflected in the television coverage of the festivities. Neither the street festivities nor the Sûfî $d h i k r$ sessions are broadcast. What can be broadcasted are religious lectures, official celebrations, Friday prayers (during or following the mawlid) and folkloric arts (such as mirmâh, a traditional Upper Egyptian horse race). This is the mawlid as the state institutions would like to show it: a well-organized and precisely orchestrated festivity for the propagation of official religious discourse. Religious dignitaries, not the ordinary visitors, are the focus of attention. The festivity is turned into a medium of religious propaganda, possibly enriched with some elements of folklore.

44. Interview with Sa'îd Mar`î; interview with General 'Adil Labîb, governor of Qena, and his secretaries on 15 January 2003 in Qena; interview with Fu'âd 'Abd al-'Azîz Muhammad. 45. Mitchell, 1988, p. $79 \mathrm{ff}$. 
However, the chaotic ambivalent traditional mawlid does not disappear. It is merely moved out of sight. By symbolically occupying the centre of the festivity (the mosque and the surrounding open space), the state can demonstrate its concern for a civilized ordered and representable mawlid and simultaneously allow the margins of the festival to follow an order of their own. After all, many of the responsible officials are well aware that this is what makes a mawlid really interesting for the majority of the participants:

We could make the mawlid even more ordered. We could go to the side streets and organise them the same way [i.e. restrict trade and amusements and decrease the pressure of the crowds], but that would make the mawlid lose its flavour. It's the crowds that make the mawlid (il-mûlid fî zahmituh). ${ }^{46}$

Thus, the state institutions must strike a balance between the interests of public appearance and order and those of the popular street festivity. This is the fundamental problem of street festivity: its continuation is in interest of the state, but at the same time it represents a potential threat to the public authorities' understanding of order and beauty and of a festivity as an officially orchestrated show.

\section{Remaking the Sûfî hadra}

Sûfî gatherings constitute the other important area in which attempts to reshape mawlids can be observed. Collective dhikr is the most important element of a public Sûfî hadra at a mawlid. This can take many forms; a dhikr involving ecstatic bodily movement and melodic, emotional music is the most prominent form at mawlids, and most commonly subject to criticism and seen as in greatest need of reform. ${ }^{47}$

Unlike the festivity on the streets, Sûfî $d h i k r$ is essentially religious in nature, however the kind of bodily disposition expressed in it is controversial. Dhikr is the main event in this most controversial kind of Sûfî gathering. After an opening ceremony with ritual speeches, prayers and recitation of the Qur'ân, the participants - members of the order or general public - stand up and start to invocate names of God while simultaneously moving to the tone of the music. The music is melodic and emotional and the munshid is usually accompanied by a band. The $d h i k r$ can last for anything from an hour to an entire night. It is usually concluded by a closing ceremony which, again, involves ritual speech and prayers. There are no lectures, no rhetorical speeches and no intellectual content. This kind of $d h i k r$ is very ecstatic and - to a certain extent - spontaneous. During a mawlid the dhikr typically takes place in a tent open to the street and it is usually

46. Interview on 18 January 2003 in Cairo with 'amîd Sayyid Ahmad, member of the National Assembly (Majlis al-Sha'b) and former police chief of Fûwa (province Kafr al-Shaykh) who has many years of experience in the mounted police during the mawlid in Disuq.

47. Frishkopf, 2002; Hoffman, 1995; Johansen, 1996; Waugh, 1989. 
quite informal: people come and go, women commonly participate in the gatherings, there are different levels of participation and only a weak differentiation between performers and audience.

Critics see the use of melodic instrumental music as compromising the spiritual content to a lower level of animalistic instincts. They also often find the mixing of men and women scandalous. The physical movement itself, i.e. the waving and dancing, is often viewed as something opposed to religion. Based on its ecstatic and spontaneous character, on the one hand, and the way it is embedded in the informal lower-class habitus of the mawlid, on the other, this kind of $d b i k r$ breaks the boundaries set for religious ritual in the dominant religious discourses.

The debate about the use of music and dance in Sûfî $d h i k r$ has a long history. ${ }^{48}$ However it has gained new urgency in the $20^{\text {th }}$ century, as attempts of modernisation have been accompanied by a tendency of objectification and rationalisation of Islam as a religion. ${ }^{49}$ From the point of view of an aesthetic of systematic, disciplined and rational piety, such practices oppose two of the fundamental principles of Islamic ritual: rationality and discipline. ${ }^{50}$ From this perspective, constrained disciplined intellectualism is the very cornerstone of the Revelation and inherently opposed to uncontrolled, ambivalent emotion: "God opened the Revelation with the word 'Read!' (iqra'), He did not say: 'Dance!'” 51

As a result, all recent attempts to reform Sûfi gatherings tend to intellectualize the content and give discipline a clear priority over emotional, ecstatic and ambivalent elements. Thus, what is important is to include intellectual, rhetorical elements in the ritual, eliminate uncontrolled expression, create clear discipline and give the whole event a more organized and morally respectable appearance.

One of the most important proponents of ritual reform is the Supreme Council of Sûfî Orders (al-Majlis al-alâ li-l-turuq al-sûfiyya), a government-controlled institution responsible for Sûfî affairs in Egypt. ${ }^{52}$ In reality, however, the Council only has a limited influence on the actual course of mawlids. It acts primarily as a vehicle for a reformist Sûfî discourse. ${ }^{53}$ Actual reforms of festivities and rituals are implemented by reform-minded Sûfî orders and individuals. ${ }^{54}$ However, just as there are different Sûfî groups with different social and ideological backgrounds,

48. Shehadi, 1995; Johansen, 1996, p. 74-82.

49. Cf. Eickelman, 1992.

50. Starrett, 1995.

51. Discussion with an Egyptian academic, Cairo, 23 January 2003.

52. Luizard, 1991, p. $29 \mathrm{ff}$.

53. Interview on 17 February 2002 in Cairo with shaykh 'Alâ' Abû 1-'Azâ'im, shaykh of the 'Azmiyya Sûfî order and a member of the Supreme Sûfî Council, who complained that the government authorities would not take seriously the Supreme Sûfî Council's proposals to eliminate deviations from mawlids.

54. It is common for living Sûfî shaykhs to have no formal order of their own, only an informal circle of friends and disciples. This is also the case with shaykh Salâh al-Dîn al-Qûsî whose hadra is described below. 
there many different ways of making a Suffi hadra fit the requirements of official religious discourses in the public sphere. In the following section, I will discuss three different solutions which I observed at different mawlids around Egypt during 2002 and 2003.

\section{Shaykh Salâh: the traditionalist}

Shaykh Salâh al-Dîn al-Qûsî (born 1940), the holder of a degree in science from a Czechoslovak university and owner of a chemical factory in the military sector, is the leader of a Sufî group which organizes one of the largest khidmas in the mawlid of al-Sayyida Zaynab in Cairo. ${ }^{55}$ During the day, the tent, which is in a good location next to the wall of the mosque, is filled by visitors who enjoy the free meals offered by the shaykh. Public hadras are held on five consecutive nights during the mawlid. I observed the opening hadra on 26 September 2002.

This hadra is traditional in much of its style, but it is clearly organized in a way that is intended to avoid the controversial aspects of Sûfî dhikrs: everybody is seated, which makes the entire event far more static and disciplined. The munshid performs without a band and in a style that consciously avoids to generate an excessively ecstatic atmosphere. Sometimes the recitation is interrupted to explain the meaning of the verse (which is authored by the shaykb). Women are seated separately from men.

Nonetheless, Shaykh Salâh's gathering remains close to the milieu and atmosphere of mawlids in many ways, and can be historically related to the long tradition of more contemplative Sûfî gatherings. There are very few speeches; the hadra consists of an opening ceremony, the performance of the munshid and a closing ceremony. ${ }^{56}$ It is open to all, people sit on the ground and not on chairs, and there is no special dress to distinguish active murîds from passers-by. The crowd participates in the inshâd, which makes the atmosphere turn ecstatic at times towards the end. This gathering has eliminated the most controversial aspects of a traditional standing musical $d h i k r$, but it is still clearly committed to the form and occasion of a traditional mawlid, ${ }^{57}$ while simultaneously attempting to create a higher level of discipline and order.

55. Shaykh Salâh's supporters are not organized in a formal association, but in an informal group known as al-Ashrâf al-Mahdiyya. Cf. http://www.alashraf-almahdia.com/.

56. In other hadras of Shaykh Salâh the programme is different. It then consists of a long sequence of prayers and hymns performed collectively by the participants. The basic setting remains the same.

57. Supporters of shaykh Salâh also abstain from criticizing other Sûfîs whose gatherings are more ecstatic and colourful. They argue that the standing dancing $d h i k r$ is simply a more basic rudimentary part of the Sûfî way, which they no longer need, thanks to the spiritual power of their shaykh. Interview with computer engineer 'Umar al-Jundî who was active in the organisation of the khidma on 29 September 2002 in Cairo. 


\section{Al-Tarîaa al-'Azmiyya: radical reform}

Other reformist Sûfî gatherings go much further than that of Shaykh Salâh. An outstanding example is the mawlid of the 'Azmiyya order. The order, which was founded in 1933 by the prominent anti-colonial activist Muhammad Mâdî Abû 1-'Azâ'im, is known for its radical anti-Salafi polemics and outspokenly modernist orientation. The 'Azmiyya defends mawlids vehemently against Salafi criticism while simultaneously calling for a reform of the celebrations. ${ }^{58}$

The mawlid of al-imâm al-mujaddid (as he is considered to be by his followers) Muhammad Mâdî Abû 1-'Azâ'im is consciously organized as an exemplary instance of a true and correct mawlid and in clear contrast to a traditional Sûfî gathering. The entire festivity consists solely of a religious-political celebration and there are no amusements and no trading to be found anywhere. The mawlid lasts four days and the atmosphere is far from festive. In 2002, the first day was devoted to a conference discussing the contribution of Sufism to religious discourse. On the second day, which was also the day of al-isrấ' wa-l-mi'râj, a celebration was held in the order's mosque involving a short $d h i k r$ - seated and without musical instruments - followed by some learned and many highly political speeches. The main public celebration took place on the two following nights, first in a tent in front of the mosque, and in the final night in a theatre.

During the public celebrations on the two last nights of the mawlid, all of the people are seated on chairs. The women are separated from men more strictly than in the hadra of Shaykh Salâh where women simply were given one part of the room whose boundaries were not physically marked. In the mawlid of the 'Azmiyya, there is a metre-high wall between the female and male audiences. In the final celebration in the theatre, women are seated on the balcony and men on the floor. There is also a clear separation between the seated audience and the order's dignitaries who are seated on the podium.

The atmosphere of the entire festivity is very formal. There is no $d h i k r$ during the public celebration. The first three and half hours of the celebration consist entirely of speakers and preachers praising the founder of the order and discussing political topics (mostly sharp attacks on Israel and Jews in general, and Saudi Arabia and Wahhabis in general). Awards are given to outstanding members of the order and persons of public prominence.

Music finally follows the three and a half hours of speeches. It is performed by an orchestra and a uniformed choir. The music is much softer and more elaborate than the music performed by most munshids in mawlids. It represents the officially recognized and more orchestral form of Sûfî music which can be appreciated as high art and broadcasted on the radio. ${ }^{59}$ The only opportunity for public participation is through applause.

58. Luizard, 1991, p. 37; AbÛ L-'AZA'IM, 1991; 1993.

59. FRISHKOPF, 2002. 
Not only does the festivity lack emotional, ecstatic and entertaining elements, the space itself is also more sober. While in other hadras, brightly-coloured traditional textiles are used for the tent, here the cloth of the tent has a simple square pattern with only two colours. This is common in many reformist hadras as well as official celebrations. Otherwise, this type of tent is used for funerals rather than mawlids.

This gathering is organized in conscious opposition to traditional mawlids. It no longer looks like a mawlid. However, it does look very much like the many official political and religious gatherings shown on Egyptian television. In fact, it represents a clear attempt to fulfil the norms of the modern official public sphere: the form is that of a conference, the public is disciplined and passive and the content is intellectual, educational and rationalistic. It is not intended to be fun.

\section{Al-Tarîqa al-Jâzûliyya: some emotion, some discipline}

The Tarîqa al-Jâzûliyya al-Husayniyya al-Shâdhiliyya, a relatively new order (established in the 1950's) that deliberately targets supporters from the welleducated upper and middle classes, adopts a different approach to making Sûfî gatherings more in tune with the dominant religious discourses. While the spiritual teachings of the order are more conventional than those of the "Azmiyya, the Jâzûliyya is very keen to perform a "clean", orderly and well-organized $d h i k r .{ }^{60}$

I observed a public gathering of the order at the mawlid of Sîdî 'Abd al-Rahîm al-Qinâwî on 18 October 2002 in Qena and at the mawlid al-nabî celebrations on 12 May 2003 in Cairo. The space for these gatherings is colourfully decorated; a brightly coloured tent, balloons and strips of coloured paper underline the festive atmosphere. The hadra features many preachers and speeches of a rhetorical - as opposed to primarily ritual - nature. However, the emphasis lies on the dhikr. The munshid performs with a band and the music bears a similarity not only to traditional Sûfî inshâd - intense, rhythmical and emotional - but also to the elaborate melodies of commercial pop music. ${ }^{61}$ The programme is based on a fixed set of songs, leaving little space for spontaneous performance. Only members of the order participate in the rituals. Some members of the order perform the music while others participate by singing and clapping hands. Many of the participants are clearly in an ecstatic state. Despite the ecstatic atmosphere, people remain seated on the ground, which is an unusual combination. Female members of the order are seated at the side of the tent and merely watch the hadra without actively participating in it. The most outstanding feature, however, is the uniform dress of the disciples, which is unique in an

60. Hoffman, 1995, p. 147, 152, 247; Johansen, 1996, p. 82-88; FrishKopf, 1999, p. $542-621$.

61. FrISHKOPF, 1999, p. 573. 
Egyptian mawlid. There are white gallâbiyyas and caps for normal murîds, green caps for those who perform and work for the khidma and blue caps for those who take care of security and order. A member of the order, who was wearing a green cap, explained that the dress code is adopted "so that there is some kind of discipline", so that different functions are clearly distinguished and so that members of the order are distinct from the crowd. As a result of this arrangement, the atmosphere is far more emotional and ecstatic than at other reformist Sûfî gatherings, however there is a clear sense of discipline which is evoked most visibly by the functional differentiation based on the uniforms.

The $d h i k r$ practised by the Jâzûliyya is very interesting because it represents an attempt to present an aesthetic of order and discipline while being festive and ecstatic at the same time. This is a central problem for all Sûfî gatherings: just as state authorities face a balancing act between the interests of public order and those of the street festivity, reform-minded Sûfîs must also strike a balance between the aim of presenting a "pure", "correct" and disciplined gathering, and the expression of festive and ecstatic tendencies. This tension between ecstatic states and group discipline, which is present in every Sûfî $d h i k r$, has been analysed by Michael Gilsenan as the polar tension between "freedom and control, between unrestrained emotional ecstasy and formal regulation, between the individual and group experience which must be one, though the first always threatens the second." ${ }^{62}$

It would be too simplistic to describe this balancing act in terms of the opposition between "orthodox" and "popular" Sufism. ${ }^{63}$ Different types of Sûfi gatherings have always existed side-by-side at Egyptian mawlids with more contemplative gatherings taking place right next to more ecstatic and spontaneous ones. ${ }^{64}$ Reformist Sûfî gatherings are not simply an expression of "orthodox" Sufism (whatever that is); they are part of a complex redefinition and remaking of spirituality, festivity and religiosity. They are closely related to the political, intellectual and economic development of Egyptian society in the $20^{\text {th }}$ century, where being both modern and a Muslim has been increasingly associated with a rational, disciplined and constrained habitus. ${ }^{65}$

For this reason, the dimension of class distinctions must not be omitted from the exploration of this phenomenon. Reformist Sûfî orders consciously try to attract educated middle or upper class followers. As a result, reformed Sûfî gatherings often stand out from the general lower-class milieu of the mawlids. Many of these gatherings have emerged only recently, and they often combine a constrained, educational atmosphere (which in itself is a marker of class distinction, especially of educational capital) with two significant innovations

\footnotetext{
62. GiLSENAN, 1973, p. 174.

63. GERHOLM, 1997, p. 143

64. Frishikopf, 2002; Abu-Zahra, 1997, p. XI; Schielke, 2002.

65. Starrett, 1995; Armbrust, 1996; EicKelman, 1992.
} 
concerning the material side of the khidma: instead of sitting together on the carpet around the plates of food, the people are seated on chairs and offered individual meals. The food is often of much higher quality than usually is provided in mawlids (it sometimes even includes elements symbolic of restaurant service, such as refreshment towels).

Many Sûfîs feel rather uncomfortable about this development, and with good reason: these "five-star khidmas" (as other Sûfîs call them), and the hadras held in them, are in some respects opposed to the milieu and atmosphere of the Sûfî mawlid, firstly, because they are associated with the outspoken criticism of the more ecstatic and emotional forms of hadra and, secondly, because of the clear statement of class difference they make by using chairs and "five-star" service. ${ }^{66}$

\section{Conclusion: the new mawlid}

Based on an understanding of "discourse itself as practice", ${ }^{67}$ the reformist discourse on mawlids is not something distinct from the festive practice itself: the game of redefining the celebrations in the public sphere goes hand in hand with changes in the time and space of the festivity.

Interestingly, this redefinition and reshaping of mawlids is largely decentral. Except for the authorization to stage the festivity, which is required from the Ministry of the Interior and in some cases from the Supreme Council of Sûfî Orders, there is no policy on mawlids at central government level. The decisions concerning the organization of a mawlid are all taken at local level by the provincial administration and by individual Sûfî orders. ${ }^{68}$

What we have here is not a centralized policy, but a diffuse discursive practice: the similarities in the reorganization of different mawlids around the country follow an implicit understanding of how large popular religious celebrations should look. This kind of discursive common sense is disseminated through the religious and civilizational discourses in the official public sphere, the institutes of higher learning, the education and training of police and security officers and the debates and discussions that take place within the Sûfî establishment.

These discursive practices of reorganization and reform primarily concern the visible aspects of the mawlids, i.e. their appearance. However, the form of the festivity is actually directly related to its content and meaning. These practices tend to eliminate or to diminish the ambivalence that is so characteristic of the traditional form of mawlid. The mawlid shall now have one clear meaning.

66. It should be kept in mind that the temporary suspension of class distinctions is a central motif of the festive time of the mawlid. Interviews with Ashraf Faysal, son and prospective successor of a Sûfî shaykh, on 1 November 2002 in Disuq; and with shaykh Hasan al-Dirîni, on 30 October 2002 in Disuq.

67. Foucault, 1972, p. 46.

68. Interviews with Sa'îd Mar'î, General 'Adil Labîb and 'amîd Sayyid Ahmad. 
Everything shall have its clear place in a spatial order and a festive programme and the people are expected to behave accordingly. These reforms attempt to transform the mawlid from a chaotic, ambivalent, utopian festivity, during which the normal order of things is suspended, into a disciplined educational celebration that reinforces norms and values. This happens in different degrees, of course. State institutions (secular and religious alike) acknowledge the ambivalence and complexity of the mawlid, but attempt to limit and control it (this is especially the case in Tanta). The 'Azmiyya Sûfî order represents an extreme position, determined to replace the traditional mawlid by an entirely different one.

According to Foucault's ${ }^{69}$ understanding of discourses as "practices that systematically form the objects of which they speak" what we have here is indeed an entirely new object: a mawlid that does not look or sound like a mawlid. However, what is happening is more complex than the mere replacement of one object by another. In practice, so far, the reforms have not led to the elimination of the more carnivalesque and syncretistic aspects of mawlids: the new object - the reformed representable mawlid - must exist in parallel to other objects, all of which are known as mawlid: the ecstatic $d h i k r$, the pilgrims in search of baraka, the children enjoying playgrounds, sweets and toys and the youths roaming the streets seeking entertainment and excitement. However, these different experiences and practices of the mawlid are being increasingly separated from each other, they are being transformed from an all-encompassing festival into separate spheres, each representing a mawlid of its own kind.

On a final note, it is important to relate the festive reform to the recent decline of mawlids ${ }^{70}$ and related traditions in Egypt. This development began in the 1990s and is most visible in the shrinking number of visitors to most mawlids and the decline of certain traditions, most importantly processions. The possible reasons for this development - changing patterns of religiosity, modern entertainment industry, the educational system and the current economic crisis are too complex to be examined here. It is necessary, however, to be aware of the relationship between the reforms, the increasing fragmentation of the festive experience and the current decline of the festivities: the traditional, carnivalesque mawlid has always been simultaneously a moment of libertine joy and a form of religious performance. When this unity of religious and festive experience breaks, the mawlid loses much of its attraction and much of its power to draw pilgrims from all parts of the country to spend a week in the temporary utopia of a sacred holiday.

Samuli SCHIELKE

International Institute for the Study of Islam in the Modern World (ISIM)

Leiden

69. Foucault, 1972, p. 49.

70. It is not possible to predict the future of the mawlids. Throughout the $20^{\text {th }}$ century, they were predicted as likely to disappear soon and went through many alternating periods of decline (e.g. the 1930s) and growth (e.g. the 1980s). Cf. McPherson, 1941; Biegman, 1990. 


\section{Bibliography}

'ABD AL-LATîF Muhammad Fahmî, 1999, [1948], Al-Sayyid al-Badawî wa-dawlat al-darâwîsh fî Misr (Maktabat al-dirâsât al-sha‘biyya; 30), Cairo, al-Hay’a al-misriyya al-'âmma li-l-kitâb.

ABÛ L-'AzÂ'IM al-Sayyid 'Izz al-Dîn Mâdî, 1991, Al-Ihtifâl bi-mawâlid al-anbiyâ' wa-lawliyâ' mushtara' la mubtada', Cairo, Dâr al-kitâb al-sûfî.

ABÔ L-'AzÂ'IM al-Sayyid 'Izz al-Dîn Mâdî, 1993, Islâm al-sûfiyya huwa l-hall la islâm al-khawârij, Cairo, Dâr al-kitâb al-sûfî.

Abu-Zahra Nadia, 1997, The Pure and Powerful. Studies in Contemporary Muslim Society, Berkshire, Ithaca Press.

Abu-Zahra Nadia, $1^{\text {st }}$ November 1999, “Taghyîrât wâsi'a bayn al-muhâfizîn: ta'yîn 16 muhâfizan jadîdan wa naql 4 wa-baqâ' 6", al-Abrâm, p. 1.

Abu-Zahra Nadia, 29 August 2002, "Tajribat muhâfazat Qinâ fî l-tanmiya al-mahalliyya namûdhaj fi idârat al-tamayyuz", al-Ahrâm.

Abu-Zahra Nadia 'Aqîdatî, 22 June 1999, "Mawlid al-Sha'râwi... tahawwal ilâ malhan li-l-darâwîsh mihrajân li-l-hummus wa-l-halwâ wa-la‘b al-atfâl!!”, p. 10-11.

ARmbrust Walter, 1996, Mass Culture and Modernism in Egypt, Cambridge, Cambridge University Press.

BaKhtine Mikhail, 1968, Rabelais and His World, Cambridge (MA), The MIT Press.

Biegman Nicolaas H., 1990, Egypt. Moulids Saints Sûfîs, Den Haag, Schwarz/Kegan.

Снiн Rachida, 2000, Le Soufisme au quotidien. Confréries d'Égypte au XXe siècle, Arles, Actes Sud.

Chit Rachida, Mayeur-Jaouen Catherine, 2002, "Le cheikh Sha'râwî et la télévision, l'homme qui a donné un visage au Coran", in Catherine Mayeur-Jaouen, éd., Saints et héros du Moyen-Orient contemporain, Paris, Maisonneuve et Larose, p. 189-209.

Eickelman Dale, 1992, "Mass Higher Education and the Religious Imagination in Contemporary Arab Societies, American Ethnologist, vol. 9, nº 4, p. 643-655.

Foucault Michel, 1972, The Archaeology of Knowledge and the Discourse on Language, New York, Pantheon Books.

Frankfurter David, ed., 1998, Pilgrimage and Holy Space in Late Antiquity Egypt, Leiden, Brill.

FIERro Maribel, 1992, "The treatises against innovations (kutub al-bida)", Der Islam, vol. 69, p. 204-246.

FrISHKOPF Michael, 1999, "Sufism, Ritual and Modernity in Egypt, Language Performance as an Adaptive Strategy", Ph. D. thesis, Los Angeles, University of California.

FrISHKOPF Michael, 2002, "Inshad Dini and Aghani Diniyya in Twentieth Century Egypt, A Review of Styles, Genres, and Available Recordings", MESA Bulletin, 34 (2), p. $167-183$.

Gerholm Tomas, 1997, “The Islamization of Contemporary Egypt”, in David WesTERLund, Eva Evers Rosander, eds., African Islam and Islam in Africa. Encounters between Sûfîs and Islamists, London, Hurst, p. 127-161.

Gilsenan Michael, 1973, Saint and Sûfî in Modern Egypt. An Essay in the Sociology of Religion, Oxford, Clarendon Press.

AL-HaJjAJî Muhammad 'Abduh, 1996, [1990], Sî̀̂ 'Abd al-Rahîm al-Qinầî al-muftarâ 'alayh, $2^{\text {nd }}$ ed., Cairo, Maktabat 'âlam al-fikr. 
Hallenberg Helena, 1997, Ibrahim al-Dasuqi (1255-96) - A Saint Invented, Helsinki, Department of Asian and African Studies, University of Helsinki.

Hoffman Valerie J., 1995, Sufism, Mystics and Saints in Modern Egypt, Columbia, University of South Carolina Press.

IвRAHÎM Muhammad Zakî, 1996, Al-Mashrûu wa-l-mamnî̀ fî qadâyâ: al-qubâb, al-mahârîb, al-masâjid wa-l-qubûr, shadd al-rihâl, al-mawâlid, ziyârat al-qubûr, masjid al-rasûl, al-tabarruk bi-l-sâlibîn... wa-ba'd mâ yata'allaq bi-kull dhâlika, Cairo, Matbû'ât wa-rasâ'il al-'Ashîra al-Muhammadiyya.

ISKANDER John, 2000, "The making of a saint: Controversial to the end and beyond, Sheikh Shaarawi continues to inspire debate”, Cairo Times, vol. 19, p. 14-17.

AL-JA'FARI Rajab al-Tayyib, 2001, Shaykh al-islâm al-Disîq $q \hat{\imath}:$ qutb al-sharî́a wa-l-haqîqa, Cairo, Maktabat Umm al-Qurâ.

JoHANSEN Julian, 1996, Sufism and Islamic Reform in Egypt. The Battle for Islamic Tradition, Oxford, Clarendon Press.

DE JoNG Frederick, "Mawlid", Encyclopaedia of Islam, 2 ${ }^{\text {nd }}$ ed., Leiden, Brill, vol. 6, p. 895-897.

DE JoNG Frederick, 1978, Turuq and Turuq-Linked Institutions in Nineteenth Century Egypt. A Historical Study in Organisational Dimensions of Islamic Mysticisnm, Leiden, Brill.

DE JONG Frederick, 1999, “Opposition to Sufism in Twentieth-Century Egypt (19001970)”, in Frederick DE JONG, Bernd RADTKE, eds., Islamic Mysticism Contested. Thirteen Centuries of Controversies and Polemics, Leiden, Brill, p. 310-323.

DE JONG Frederick, 2000, Sûfî Orders in Ottoman and Post-Ottoman Egypt and the Middle East, Collected Studies, Istanbul, The Isis Press.

Kaptein N.J.G., 1993, Muhammad's Birthday Festival: Early History in the Central Muslim Lands and Development in the Muslim West until the $10^{\text {th }} 16^{\text {th }}$ Century, Leiden, Brill.

LANE Edward William, 1989, 1836, An Account of the Manners and Customs of the Modern Egyptians, reprint of the 1895 edition, London, East-West Publications.

al-Liwâa' al-islâmî, $1^{\text {st }}$ August 2002, "Shaykh al-turuq al-sûfiyya li-1-Liwâ' al-islâmî: al-ladhîna yuhâjimûn al-tasawwuf lam yaqra'û târîkh rijâlih bi-'ayn al-insâf: iqâmat al-mawâlid lahâ shar'iyyatuhâ wa l-tasawwuf laysa mas'ûlan 'an salbiyyâtihâ”, p. 4-5.

LUIZARD Pierre-Jean, 1991, "Le rôle des confréries soufies dans le système politique égyptien”, Monde arabe Maghreb Machrek, 131, p. 26-53.

Madeuf Anna, 2001, "Les grands mûlid-s : des vieux quartiers du Caire aux territoires de l'islam”, in Guy Di Méo, éd., La géographie en fêtes, Paris, Ophrys, p. 155-265.

Martinovich N., 1912, "Prazdnik v Tante”, Mir Islama, vol. 1, p. 517-522.

MAYeur-JaOuen Catherine, 1994, Al-Sayyid al-Badawî. Un grand saint de l'islam égyptien, Le Caire, Institut Français d'Archéologie Orientale.

Mayeur-Jaouen Catherine, 1995, "Égypte”, in Henri Chambert-Loir, Claude Guillot, éds., Le culte des saints dans le monde musulman, Paris, École française d'ExtrêmeOrient, p. 61-73.

McPherson J.W., 1941, The Moulids of Egypt (Egyptian Saint-Days), Cairo.

Meinardus Otto F.A., 2002, Coptic Saints and Pilgrimages, Cairo, American University in Cairo Press. 
Mitchell Timothy, 1988, Colonising Egypt, Cambridge, Cambridge Univ. Press.

MustafÂ Fârûq Ahmad, 1981, Al-Mawâlid: dirâsa li-l-âdât wa-l-taqâlîd al-sha'biyya fî Misr, $2^{\text {nd }}$ ed., Alexandria, al-Hay'a al-misriyya al-'âmma li-l-kitâb.

VAN NieUWKerk Karin, 1995, 'A Trade like any Other'. Female Singers and Dancers in Egypt, Austin, University of Texas Press.

Pagès-el-Karoui Delphine, 2002, Lectures Spatiales du Mouled de Sayyid al-Badawi à Tanta. Paper presented to the $1^{\text {st }}$ World Congress for Middle Eastern Studies, Mainz. QÂDI Sa'd, 2001, Al-'Ârif bi-llâh Sîdî Ahmad al-Badawî̀, Cairo, Dar al-gharîb.

SCHIELKE Samuli, 2001, "Pious Fun at Saints Festivals in Modern Egypt”, ISIM Newsletter, vol. 7 , p. 23.

SCHIELKE Samuli, 2002, “Mâ l-sha'bî fî l-mu'taqadât al-sha'biyya”, Fusûl, 60, p. 166-176.

SCHIElKe Samuli, 2003, "Habitus of the Authentic, Order of the Rational: Contesting Saints Festivals in Contemporary Egypt", Critique. Critical Middle Eastern Studies, 12 (2), p. 155-172.

AL-SHA'RÂNI Abû 1-Mawâhib 'Abd al-Wahhâb b. Ahmad, 1997, Al-Tabaqât al-kubrâ al-musammât bi-lawâhiq al-anwâr fî tabaqât al-akbyâr, Khalîl MANsur, ed., Beirut, Dâr al-kutub al-'ilmiyya.

SHEHADI Fadlou, 1995, Philosophies of Music in Medieval Islam, Leiden, Brill.

Shoshan Boaz, 1993, Popular Culture in Medieval Cairo, Cambridge, Cambridge University Press.

STARRETT Gregory, 1995, "The hexis of interpretation: Islam and the body in the Egyptian popular school”, American Ethnologist, 22 (4), p. 953-969.

STAUTH Georg, 2001, "Skizzen zur materiellen Kultur des religiösen Ortes (Islam)", in H. Schrader, M. KaIser, R. KorfF, eds., Markt, Kultur, und Gesellschaft, Münster, Lit-Verlag, p. 149-166.

TURNER Victor W., 1974, The ritual process: structure and anti-structure, Harmondsworth, Penguin Books.

'UMAR Muhammad, 1902, Hâdir al-misriyyîn aw sirr ta'akhkhuribim, Cairo, Matba'at al-Muqtataf.

al-Wafd, 6 November 2002, "Wafât al-mutashâr 'Alî 'Abd al-Shakûr muhâfiz Kafr al-Shaykh", p. 1.

WaLlin Georg August, 1864, Georg August Wallins reseanteckningar från Orienten åren 1843-1849: Dagbok och bref, Sven Gabriel Elmgren, ed., 4 vols, Helsinki, Frenckell.

Waugh Earle H., 1989, The Munshidin of Egypt: Their World and Their Song, Columbia, University of South Carolina Press.

WINTER Michael, 1982, Society and Religion in Early Ottoman Egypt: Studies in the Writings of 'Abd al-Wahhab al-Sha'rani, New Brunswick etc., Transaction Books.

"Ziyâra”, Encyclopaedia of Islam, $2^{\text {nd }}$ ed., vol. 9, Leiden, Brill, p. 524-539. 


\section{Résumé}

Les festivités entourant les mawlids en Égypte font régulièrement l'objet de critiques qui visent leur caractère "inculte" et l'accusent de constituer une innovation nonislamique (bid'a). Ces critiques ont eu pour effet de susciter différentes tentatives de réformer le déroulement de ces festivités. Dans le passé récent, les institutions d'État se sont efforcés de donner une apparence plus "civilisée " et "ordonnée " aux célébrations et cet objectif est partagé dans une grande mesure par certains ordres soufis qui ont également cherché à réformer les mawlids. Le caractère utopique de ces festivités a été modifié de manière considérable par l'introduction de nouvelles pratiques qui visent à transformer le mawlid, lieu de suspension de l'ordre normal des choses, en un spectacle éducatif qui contribuerait justement à consolider cet ordre par le renforcement de ses normes et ses valeurs.

Mots-clés : Égypte, fêtes, soufisme, mawlid, urbanisme, réforme islamique.

\section{Abstract}

Egyptian mawlid festivals are regularly subject to criticism which describes them as an uncivilised and un-Islamic bid'a. In response to this, attempts to reform mawlids have emerged in the recent years. State institutions attempt to reorganise mawlids to give them a more "civilised" and "ordered" appearance, while some Sîfî orders reshape their festive practice, following similar objectives. These practices significantly alter the character of the festivities, attempting to transform them from a utopian festivity where the normal order of things is suspended, into an educational celebration where norms and values are reinforced.

Key words: Egypt, festivals, sufism, mawlid, urban planning, Islamic reform.

Las festividades que rodean los mawlid en Egipto son, regularmente, objeto de críticas que apuntan a su carácter "inculto " y lo acusan de constituir una innovación no islámica (bid'a). El efecto de estas críticas ha culminado en diferentes intentos de reformar el desarrollo de estas festividades. En el pasado reciente, las instituciones de estado se han esforzado por dar una apariencia más "civilizada " $y$ "ordenada" a las celebraciones, y este objetivo es compartido en gran medida por ciertas órdenes sufis que han igualmente intentado reformar los mawlids. El carácter utópico de estas festividades ha sido modificado de manera considerable por la introducción de nuevas prácticas que apuntan a transformar el mawlid, lugar de suspensión del orden normal de las cosas en un espectáculo educativo que contribuiría justamente a consolidar este orden a través del refuerzo de sus normas y sus valores.

Palabras claves : Egipto, fiestas sufismo, mawlid, plan urbano, reforma islámica. 